\title{
Corrosion Protection of Steel Parts in Aircraft by Zn-Mn Alloy Electrodeposits
}

\author{
M. Bucko ${ }^{*}$, Z. Velickovic ${ }^{\dagger}$, J. Bajat ${ }^{\ddagger}$ and M. Stojanovic ${ }^{\S}$
}

\begin{abstract}
Electrodeposited $\mathrm{Zn}-\mathrm{Fe}, \mathrm{Zn}-\mathrm{Co}$ and $\mathrm{Zn}-\mathrm{Ni}$ alloy coatings are widely used for corrosion protection of steel nowadays. Several authors have reported that in aggressive environments, such as atmosphere containing $\mathrm{SO}_{2}$ and chloride compounds, $\mathrm{Zn}-\mathrm{Mn}$ alloy coatings can have even better corrosion resistance. Besides, these alloys possess high hardness and they can easily be painted. Good characteristics of $\mathrm{Zn}-\mathrm{Mn}$ alloys suggest their possible application in protection of steel parts, especially in automobile and aircrafts. In the last ten years, three new types of electrolytic solutions for electrodeposition of $\mathrm{Zn}-\mathrm{Mn}$ alloys were proposed, namely acidic chloride and sulphate and alkaline pyrophosphate solution.
\end{abstract}

The scope of this work was to compare the corrosion protection ability of $\mathrm{Zn}-\mathrm{Mn}$ alloy coatings electrodeposited under various parameters, such as type of electrolytic solution, concentration of metal ions in solution and deposition current density. Recording of corrosion potential and salt spray chamber measurements were used to investigate the corrosion stability of $\mathrm{Zn}-\mathrm{Mn}$ coatings. It was concluded that $\mathrm{Zn}-\mathrm{Mn}$ alloy had better corrosion resistance than pure $\mathrm{Zn}$, due to the formation of compact protective-passive layer in chloride containing media. Among various $\mathrm{Zn}-\mathrm{Mn}$ electrodeposits, the best corrosion behavior was obtained for the ones deposited from chloride solution, at current densities between 3 and $8 \mathrm{~A} \mathrm{dm}^{-2}$.

Keywords: Zn-Mn alloys, corrosion, salt spray chamber, steel protection

\section{Introduction}

The main demands for materials used in aircraft manufacture are to be corrosion and heat resistant, light, strong materials that are easily machined, assembled and repaired. Currently, materials used for this purpose are aluminum alloys, titanium and composites [1]. Stainless or coated steel are used for aircraft parts with special mechanical and electrical usage, such as turning parts, precision casting parts, engine parts, transmission components, fittings, landing gear trunnions etc $[1,2]$.

Electrodeposition of sacrificial coatings of zinc and its alloys, particularly Zn-Fe, Zn-Co and $\mathrm{Zn}-\mathrm{Ni}$, is a widely used method that provides corrosion protection of steel parts [3]. However,

\footnotetext{
*Assistant Professor, Military Academy, 33 Gen. Pavle Jurisic Sturm St., Belgrade, Serbia, mihaelbucko@yahoo.com

$\dagger$ Assistant Professor, Military Academy, 33 Gen. Pavle Jurisic Sturm St., Belgrade, Serbia, zlatevel@yahoo.com.

$\$$ Associate Professor, Faculty of Technology and Metallurgy, University of Belgrade, P.O.Box 3503, YU-11120 Belgrade, Serbia, jela@tmf.bg.ac.rs .

${ }^{\S}$ Senior researcher, Military Technical Institute, Ratka Resanovica 1, Belgrade, Serbia.
} 
for corrosion protection of steel under severe atmospheric conditions, in particular in the presence of $\mathrm{SO}_{2}$ and chloride compounds, various alternative materials are being investigated. Among those materials are the zinc-manganese alloys, which have been reported to show better corrosion resistance properties than other zinc alloys. $\mathrm{Zn}-\mathrm{Mn}$ system seems to display both improved corrosion resistance and hardness and good environmental compatibility, so it is acceptable for protection of aircraft steel parts $[4,5]$.

Zn-Mn coatings are less thermodynamically noble than $\mathrm{Zn}$, but they show a passivating behavior in various environments due to the formation of insoluble compounds on the corroding surface. Depending on aggressive media, various compounds were found in passive layer, such as oxides $\mathrm{MnO}, \mathrm{Mn}_{0.98} \mathrm{O}_{2}, \mathrm{Mn}_{5} \mathrm{O}_{8}$ [6] and $\gamma-\mathrm{Mn}_{2} \mathrm{O}_{3}$ [7], or basic salts like $\mathrm{Zn}_{4}(\mathrm{OH})_{6} \mathrm{SO}_{4} \cdot \mathrm{xH}_{2} \mathrm{O}$ and $\mathrm{Zn}_{5}(\mathrm{OH})_{8} \mathrm{Cl}_{2} \cdot \mathrm{H}_{2} \mathrm{O}$ [8].

Corrosion stability of electrodeposited alloy coating depends on its surface morphology, chemical and phase composition. These properties are strongly influenced by the type of electrolytic solution used for electrodeposition and plating parameters, such as deposition current density, temperature, stirring of the solution, etc. [9]. The scope of this work was to compare the corrosion protection of $\mathrm{Zn}-\mathrm{Mn}$ alloy coatings electrodeposited at various deposition current densities. Three different electrolytic solutions were used: slightly acidic chloride and sulphate solution and alkaline pyrophosphate solution. The change of corrosion potential with time of immersion in $\mathrm{NaCl}$ solution and salt spray chamber measurements were used to investigate the corrosion stability of $\mathrm{Zn}-\mathrm{Mn}$ coatings. The surface coatings roughness was also measured, in order to examine the surface morphology of the coatings.

\section{Experimental Work}

Electrodeposition of Zn-Mn alloys was performed on steel panels galvanostatically, at various current densities, of 1-12 $\mathrm{A} \mathrm{dm}^{-2}$. Deposition times were managed to obtain layers of typically $10 \mu \mathrm{m}$ thickness. The composition of the plating baths used is presented in Table 1. All solutions were made from analytical grade chemicals (Sigma Aldrich) and double distilled water.

The electrodeposition process was carried out in a classical three-electrode glass cell, at the temperature of $20 \pm 2{ }^{0} \mathrm{C}$ in aerated conditions, without stirring. Working electrodes were steel panels. Prior to each experiment, the steel surfaces were polished successively with emery papers of the following grades: 600, 1000, 1200 and then degreased in a saturated solution of $\mathrm{NaOH}$ in ethanol, pickled with a $2 \mathrm{~mol} \mathrm{dm}^{-3} \mathrm{HCl}$ solution for $30 \mathrm{~s}$ and finally rinsed with distilled water. Cylindrical $\mathrm{Zn}$ foil (high purity zinc, 99.9 mass\%), placed close to the cell walls, was used as a counter electrode, providing good current distribution in the cell, since working electrode was placed in the middle of the cell. The reference electrode was a saturated calomel electrode (SCE).

Table 1 Composition of plating baths

\begin{tabular}{lc|lc|lc}
\hline \hline Chloride & $\boldsymbol{c} / \mathbf{~ m o l ~ d m}$ & Sulphate & $\boldsymbol{c} / \mathbf{m o l ~ d m}$ & Pyrophosphate & $\boldsymbol{c} / \mathbf{m o l ~ d m}^{-3}$ \\
\hline \hline $\mathrm{KCl}$ & 3.2 & $\mathrm{MnSO}_{4} \cdot \mathrm{H}_{2} \mathrm{O}$ & 0.30 & $\mathrm{~K}_{4} \mathrm{P}_{2} \mathrm{O}_{7}$ & 1.0 \\
$\mathrm{H}_{3} \mathrm{BO}_{3}$ & 0.42 & $\mathrm{ZnSO}_{4} \cdot 7 \mathrm{H}_{2} \mathrm{O}$ & 0.30 & ascorbic acid & 0.03 \\
$\mathrm{ZnCl}_{2}$ & 0.45 & $(\mathrm{NH} 4)_{2} \mathrm{SO}_{4}$ & 0.49 & $\mathrm{MnCl}_{2} \cdot 4 \mathrm{H}_{2} \mathrm{O}$ & 0.05 \\
$\mathrm{MnCl}_{2} \cdot 4 \mathrm{H}_{2} \mathrm{O}$ & 0.45 & & $\mathrm{ZnCl}_{2}$ & 0.05 \\
\hline \hline
\end{tabular}


The corrosion behavior of the Zn-Mn coatings was first studied by neutral salt spray tests, according to ASTM B-117-07a standard, using a Q-panel chamber (Mod. CCT-1100). The tests were performed using a $0.5 \mathrm{~mol} \mathrm{dm}^{-3} \mathrm{NaCl}$ solution with a $\mathrm{pH}$ in the range of 6.5-7.2. For these tests, the coatings were deposited on steel panel $(30 \times 50 \mathrm{~mm})$. The exposure time was recorded at which red corrosion was first observed; such corrosion is associated with the oxidation of the steel substrate.

The deposit thickness was $\sim 10 \mu \mathrm{m}$, measured by Coating Thickness Measuring Instrument DUALSCOPE MPOR. Chemical composition of electrodeposited Zn-Mn alloys was determined by atomic absorption spectrophotometry, using atomic spectrophotometer PYE Unicam SP9, Philips. The $10 \mu \mathrm{m}$ thick pure zinc coatings were also tested in salt spray test, for comparison.

In addition, the corrosion behavior of $\mathrm{Zn}-\mathrm{Mn}$ coatings was studied by following the corrosion potential $\left(E_{\text {corr }}\right)$ during exposure to aerated $0.5 \mathrm{~mol} \mathrm{dm}^{-3} \mathrm{NaCl}$ solution, until the $\mathrm{E}_{\text {corr }}$ of the steel substrate was reached. Steel panels $(20 \times 20 \mathrm{~mm})$ were used as substrate for alloy coating deposition. The deposit thickness was also $10 \mu \mathrm{m}$. The corrosion potential was recorded by a potentiostat / galvanostat ZRA Reference 600, Gamry Instrument.

Roughness of the Zn-Mn deposits was measured using TR200 Surface Roughness Tester. Results were recorded by computer attached to the surface tester, using software TR200 Time Data View.

\section{Results and Discussion}

\subsection{Salt Spray Chamber}

To evaluate the protective capacity of the Zn-Mn coatings on the steel substrate, salt spray tests were performed. The results obtained are presented in Table 2 and they show that most of the $\mathrm{Zn}-\mathrm{Mn}$ samples lasted longer before the appearance of red corrosion, as compared to pure $\mathrm{Zn}$ samples. Manganese contents in these alloys, determined by atomic absorption spectrophotometry, are presented also in Table 2 . These results clearly prove that plating baths investigated in this work can be successfully used for electrodeposition of $\mathrm{Zn}-\mathrm{Mn}$ alloys, in order to increase the corrosion stability of pure $\mathrm{Zn}$ coatings.

However, there is a significant difference in the salt spray test behavior between $\mathrm{Zn}-\mathrm{Mn}$ coatings deposited under various conditions. It can be noticed that coatings deposited at the highest deposition current densities ( $8 \mathrm{i} 12 \mathrm{~A} \mathrm{dm}^{-2}$ ) withstood considerably shorter exposure time before the onset of red corrosion, compared to samples deposited at lower current densities. After 96 hours of exposure in the salt spray chamber, minimal damage was observed at samples deposited from chloride solution, with metal ions ratio of $\left[\mathrm{Mn}^{2+}\right]:\left[\mathrm{Zn}^{2+}\right]$ $=4: 1$, at current density of $3 \mathrm{~A} \mathrm{dm}^{-2}$.

\subsection{Corrosion Properties of Zn-Mn Alloys in Aqueous Solution}

In order to determine the corrosion stability in chloride media, the plated specimens were immersed in $0.5 \mathrm{~mol} \mathrm{dm}^{-3} \mathrm{NaCl}$ solution and the $\mathrm{E}_{\text {corr }}$ was measured daily. Fig. 1 shows the time dependence of $E_{\text {corr }}$ for steel plated by $\mathrm{Zn}-\mathrm{Mn}$ alloys deposited from three different plating baths. The $E_{\text {corr }}$ of bare steel surface in $0.5 \mathrm{~mol} \mathrm{dm}^{-3} \mathrm{NaCl}$ was $-640 \mathrm{mV}$ vs. SCE and it is marked with a line in Figure 1 . The potential of $\mathrm{Zn}-\mathrm{Mn}$ alloys is more negative than $E_{\text {corr }}$ of steel base, so $\mathrm{Zn}-\mathrm{Mn}$ deposits offer sacrificial cathodic protection. The $E_{\text {corr }}$ values of steel 
modified by $\mathrm{Zn}-\mathrm{Mn}$ alloys increase positively with time of immersion and reach the steel $E_{\text {corr }}$, which represents the deposit loss and start of the corrosion process at the substrate.

The time of reaching the steel $E_{\text {corr }}$ for different specimens is presented in Table 3. Similarly to the salt spray chamber results, the best corrosion stability of $\mathrm{Zn}-\mathrm{Mn}$ coatings is obtained by deposition from chloride solution. The coatings deposited at lower current densities showed higher stability.

The time for the red rust appearance, i.e. for reaching the $E_{\text {corr }}$ of the steel substrate, is determined by two factors, thermodynamic and kinetic ones. The first factor refers to the initial $E_{\text {corr }}$ value of the alloy. As a rule, alloys with more positive initial $E_{\text {corr }}$ value are thermodynamically more stable and the change of their $E_{\text {corr }}$ toward the steel $E_{\text {corr }}$ is slower [3]. As Figure 1 depicts, the $E_{\text {corr }}$ of $\mathrm{Zn}-\mathrm{Mn}$ alloys obtained at different parameters, slightly differs initially, which can be attributed to the alloy phase difference and the difference in the chemical composition. Kinetically factor which determines corrosion stability of the Zn-Mn alloy specimens refers to the formation of protective corrosion product layer on the corroding surface. Figure 1 reveals that after 24 hours of immersion in $0.5 \mathrm{~mol} \mathrm{dm}^{-3} \mathrm{NaCl}$ solution, all specimens have very close $E_{\text {corr }}$ values. After this point, $E_{\text {corr }}$ values reach a plateau for all investigated samples. This is strong evidence that protective layer is formed on corroding samples [10]. The abrupt change of the immersion potential in positive direction, for prolonged immersion times, indicates that contact of the electrolyte with Fe-substrate is made through possible pinholes of the Zn-Mn electrodeposits, which means that the protective layer on the $\mathrm{Zn}-\mathrm{Mn}$ coating is disturbed and degradation of the coating and the substrate occurs.

Table 2 The exposure time at which oxidation of the steel substrate (red corrosion) was first observed in the salt spray test.

\begin{tabular}{l|c|c|c}
\hline \hline Plating solution & $\begin{array}{c}\text { Deposition current } \\
\text { density / } \mathbf{A ~ d m}\end{array}$ & $\begin{array}{c}\text { Mn content in the } \\
\text { coating (mass. \%) }\end{array}$ & Time / h \\
\hline \hline chloride, $\left[\mathrm{Mn}^{2+}\right]:\left[\mathrm{Zn}^{2+}\right]=2: 1$ & 3 & 1.5 & 72 \\
\hline chloride, $\left[\mathrm{Mn}^{2+}\right]:\left[\mathrm{Zn}^{2+}\right]=2: 1$ & 8 & 6.3 & 24 \\
\hline chloride, $\left[\mathrm{Mn}^{2+}\right]:\left[\mathrm{Zn}^{2+}\right]=2: 1$ & 12 & 9.9 & 8 \\
\hline chloride, $\left[\mathrm{Mn}^{2+}\right]:\left[\mathrm{Zn}^{2+}\right]=1: 1$ & 3 & 0.5 & 72 \\
\hline chloride, $\left[\mathrm{Mn}^{2+}\right]:\left[\mathrm{Zn}^{2+}\right]=1: 1$ & 8 & 1.1 & 8 \\
\hline chloride, $\left[\mathrm{Mn}^{2+}\right]:\left[\mathrm{Zn}^{2+}\right]=1: 2$ & 3 & 0.4 & 72 \\
\hline chloride, $\left[\mathrm{Mn}^{2+}\right]:\left[\mathrm{Zn}^{2+}\right]=1: 2$ & 8 & 0.9 & 8 \\
\hline chloride, $\left[\mathrm{Mn}^{2+}\right]:\left[\mathrm{Zn}^{2+}\right]=4: 1$ & 3 & 0.7 & 72 \\
\hline chloride, $\left[\mathrm{Mn}^{2+}\right]:\left[\mathrm{Zn}^{2+}\right]=4: 1$ & 8 & 6.2 & 24 \\
\hline Sulphate & 3 & 1.2 & 72 \\
\hline Sulphate & 5 & 3.5 & 24 \\
\hline Pyrophosphate & 3 & 4.7 & 24 \\
\hline Pyrophosphate & 8 & 10.1 & 8 \\
\hline pure $\mathrm{Zn}$ & 3 & 0 & 24 \\
\hline pure $\mathrm{Zn}$ & 8 & 0 & 24 \\
\hline pure $\mathrm{Zn}$ & 11 & 0 & 24 \\
\hline
\end{tabular}



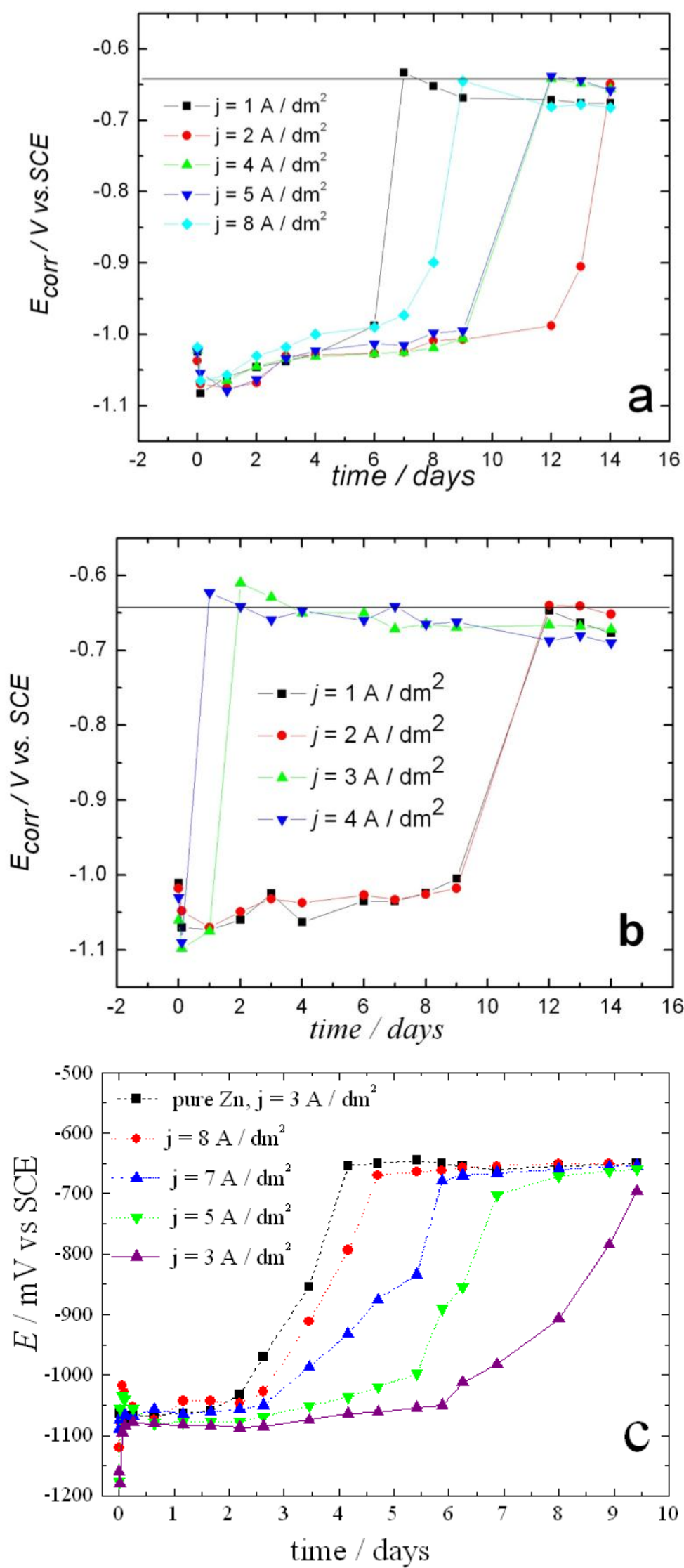

Fig. 1. The dependence of $E_{\text {corr }}$ with time of immersion in $0.5 \mathrm{~mol} \mathrm{dm}^{-3} \mathrm{NaCl}$ solution, for pure $\mathrm{Zn}$ and $\mathrm{Zn}-\mathrm{Mn}$ alloys deposited from: a) chloride solution, $\left[\mathrm{Mn}^{2+}\right]:\left[\mathrm{Zn}^{2+}\right]=\mathbf{2 : 1}$;

b) sulphate solution, $\left[\mathrm{Mn}^{2+}\right]:\left[\mathrm{Zn}^{2+}\right]=1: 1$ and

c) pyrophosphate solution, $\left[\mathrm{Mn}^{2+}\right]:\left[\mathrm{Zn}^{2+}\right]=1: 1$ 
Table 3 The exposure time after which $E_{\text {corr }}$ of the steel substrate was reached in the $0.5 \mathrm{~mol} \mathrm{dm}^{-3} \mathrm{NaCl}$ solution

\begin{tabular}{|c|c|c|c|}
\hline Solution & {$\left[\mathrm{Mn}^{2+}\right]:\left[\mathrm{Zn}^{2+}\right]$} & $j / \mathrm{A} \mathrm{dm}^{-2}$ & Time / days \\
\hline \multirow{16}{*}{ Chloride } & \multirow{3}{*}{$1: 1$} & $\bar{~} 1$ & 9 \\
\hline & & 2 & 17 \\
\hline & & 7 & 14 \\
\hline & \multirow{4}{*}{$1: 2$} & 1 & 9 \\
\hline & & 2 & 9 \\
\hline & & 4 & 12 \\
\hline & & 11 & 12 \\
\hline & \multirow{5}{*}{$2: 1$} & 1 & 7 \\
\hline & & 2 & 14 \\
\hline & & 4 & 11 \\
\hline & & 5 & 11 \\
\hline & & 8 & 9 \\
\hline & \multirow{4}{*}{$4: 1$} & 3 & 12 \\
\hline & & 5 & 12 \\
\hline & & 7 & 9 \\
\hline & & 9 & 9 \\
\hline \multirow{4}{*}{ Sulphate } & \multirow{4}{*}{$1: 1$} & 1 & 12 \\
\hline & & 2 & 12 \\
\hline & & 3 & 4 \\
\hline & & 4 & 2 \\
\hline \multirow{4}{*}{ Pyrophosphate } & \multirow{4}{*}{$1: 1$} & 2 & 7 \\
\hline & & 3 & 6 \\
\hline & & 8 & 6 \\
\hline & & 12 & 5 \\
\hline
\end{tabular}

\subsection{Surface Roughness}

In order to examine surface morphology of electrodeposited $\mathrm{Zn}-\mathrm{Mn}$ alloy coatings, roughness of the surfaces was measured at the length of $2.5 \mathrm{~mm}$, as it is shown in Figure 2. The parameters obtained were as follows: $R_{a}$ - average roughness, i.e. the arithmetical average deviation of the surface profile (equation 1 ) and $R_{z}$ - the maximum height of irregularities (equation 2).

$$
\begin{aligned}
& R_{a}=\frac{1}{n} \sum_{i=1}^{n}\left|y_{i}\right| \\
& R_{z}=R_{v}+R_{d}
\end{aligned}
$$



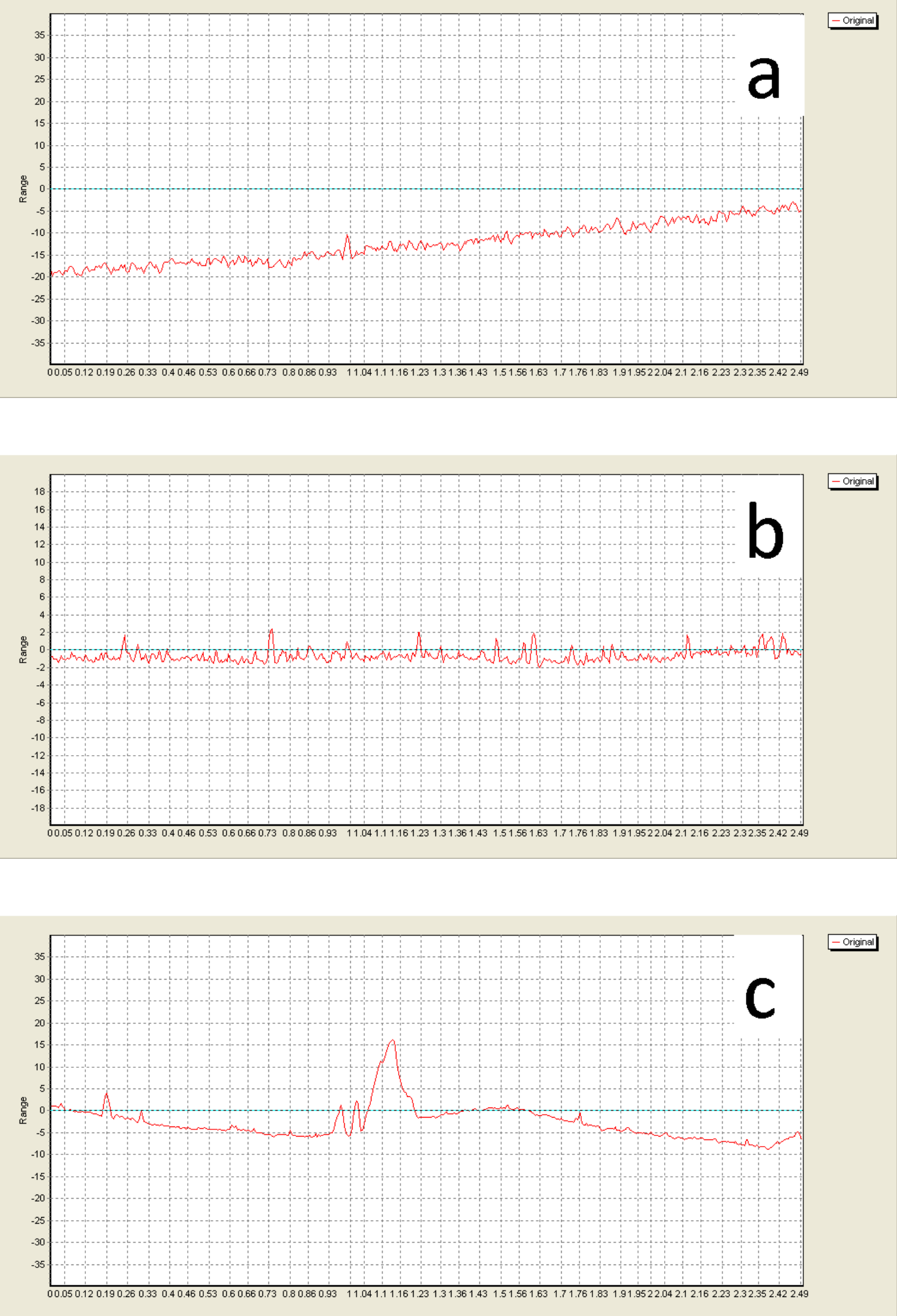

Figure 2 Profile lines for $\mathrm{Zn}-\mathrm{Mn}$ alloy surfaces deposited at $3 \mathrm{~A} \mathrm{dm}^{-2}$ from a) chloride; b) sulphate and c) pyrophosphate solution. 
Surface roughness of the electrodeposited coating gives information about homogeneity of the coating, size distribution of crystalline grains, and current density distribution on the working electrode [11]. Low values of $R_{a}$ and $R_{z}$ parameters for one coating indicate that the coating is homogeneous, non-porous and defect free. So, compact protective layer of corrosion product has better chance to form on the surface with low roughness [11].

Table 4 depicts calculated roughness parameters. Some conclusions about the course of the change in the surface roughness of $\mathrm{Zn}-\mathrm{Mn}$ coatings with change of deposition parameters can be made based on the results shown in table 4 and Figure 2. First, independently on plating solution used, the increase in deposition current density results with the increase in roughness of deposits. Second, when plating solutions are compared, it can be seen that coatings deposited from the sulphate solution possess the lowest roughness, and coatings deposited from chloride solution are just slightly coarser. Contrary, deposits obtained from alkaline pyrophosphate solution possess significantly higher roughness.

As a conclusion, roughness results are in correlation with corrosion investigations to some extent. Smoother specimens have shown higher corrosion resistance and vice versa. It is strong evidence that the most important factor in corrosion stability of $\mathrm{Zn}-\mathrm{Mn}$ alloys is the stability of corrosion product layer on their surface.

Table 4. Roughness parameters for $\mathrm{Zn}$-Mn coatings deposited under various conditions

\begin{tabular}{l|c|c|c}
\hline Solution & $j / \mathrm{A} \mathrm{dm}^{-2}$ & $R_{a} / \mu \mathrm{m}$ & $R_{z} / \mu \mathrm{m}$ \\
\hline \hline chloride, $\left[\mathrm{Mn}^{2+}\right]:\left[\mathrm{Zn}^{2+}\right]=1: 2$ & 3 & 0,748 & 6,46 \\
\hline chloride, $\left[\mathrm{Mn}^{2+}\right]:\left[\mathrm{Zn}^{2+}\right]=1: 1$ & 3 & 0,528 & 3,42 \\
\hline chloride, $\left[\mathrm{Mn}^{2+}\right]:\left[\mathrm{Zn}^{2+}\right]=2: 1$ & 3 & 0,658 & 5,26 \\
\hline chloride, $\left[\mathrm{Mn}^{2+}\right]:\left[\mathrm{Zn}^{2+}\right]=4: 1$ & 3 & 0,904 & 15,97 \\
\hline Sulphate & 3 & 0,42 & 3,88 \\
\hline Pyrophosphate & 3 & 2,754 & 23,39 \\
\hline chloride, $\left[\mathrm{Mn}^{2+}\right]:\left[\mathrm{Zn}^{2+}\right]=1: 2$ & 8 & 1,652 & 13,03 \\
\hline chloride, $\left[\mathrm{Mn}^{2+}\right]:\left[\mathrm{Zn}^{2+}\right]=1: 1$ & 8 & 0,847 & 6,94 \\
\hline chloride, $\left[\mathrm{Mn}^{2+}\right]:\left[\mathrm{Zn}^{2+}\right]=2: 1$ & 8 & 0,874 & 10,81 \\
\hline Pyrophosphate & 8 & 2,989 & 30,84 \\
\hline chloride, $\left[\mathrm{Mn}^{2+}\right]:\left[\mathrm{Zn}^{2+}\right]=1: 1$ & 12 & 1,274 & 14,3 \\
\hline chloride, $\left[\mathrm{Mn}^{2+}\right]:\left[\mathrm{Zn}^{2+}\right]=2: 1$ & 12 & 1,159 & 9,659 \\
\hline chloride, $\left[\mathrm{Mn}^{2+}\right]:\left[\mathrm{Zn}^{2+}\right]=4: 1$ & 12 & 1,96 & 18,02 \\
\hline \hline
\end{tabular}

\section{Conclusion}

Although main aircraft materials are light metals like titanium and aluminum alloys, the use of steel is unavoidable for some parts of the aircraft. Zn-Mn alloy coatings are recognized as successful possible method to protect steel surface from corrosion, due to their stability in aggressive atmosphere and high hardness. 
Zn-Mn coatings can be electrodeposited from various plating solutions. In this work, three plating solutions were used and corrosion stability of obtained deposits was examined. It was shown that coatings obtained from chloride solutions possessed significantly higher corrosion stability in comparison with sulphate and pyrophosphate solutions. The best corrosion performance possessed coatings deposited at current densities in the range of $2-5 \mathrm{~A} \mathrm{dm}^{-2}$. Surface morphology of the deposits was examined through the roughness measurements. It was concluded that coatings obtained from slightly acidic solutions are significantly smoother as compared to the coatings from alkaline pyrophosphate solution. Also, it was shown that smoother coatings possess better corrosion stability in chloride media.

\section{References}

[1] Mraz S.J., "A Century of Progress in Aircraft Materials-Part 2 Metals", Machine Design, November 6, 2003, http://www.machinedesign.com.

[2] Bozzini B., Accardi V., Cavallotti P.L. and Pavan F., "Electrodeposition and plastic behavior of low-manganese zinc-manganese alloy coatings for automotive applications", Automotive finishing, May 1999, pp. 33-42.

[3] Hammami O., Dhouibi L., Triki E., "Influence of $\mathrm{Zn}-\mathrm{Ni}$ alloy electrodeposition techniques on the coating corrosion behavior in chloride solution", Surf. and Coat. Technol., 203, 2009, pp. 2863-2870.

[4] Boshkov N., "Galvanic Zn-Mn alloys: electrodeposition, phase composition, corrosion behavior and protective ability", Surf. and Coat. Technol., 172, 2003, pp. 217-226.

[5] Eyraud M., Garnier A., Mazeron F., Crousier J., "Morphology and composition of electrodeposited zinc-manganese alloys", Plat. Surf. Finish. 82, 1995, pp. 63-70.

[6] Ortiz Z.I., Díaz-Arista P., Meas Y., R. Ortega-Borges, G. Trejo, "Characterization of the corrosion products of electrodeposited $\mathrm{Zn}, \mathrm{Zn}-\mathrm{Co}$ and $\mathrm{Zn}-\mathrm{Mn}$ alloys coatings", Corros. Sci., 51, 2009, pp. 2703-2715.

[7] L.Ballote, R.Ramanauskas, P. Perez, "Mn oxide film as corrosion inhibitor of $\mathrm{Zn}-\mathrm{Mn}$ coatings", Corr. Reviews, 18, 2000, pp. 41-51.

[8] N. Boshkov, K. Petrov, G. Raichevsky, "Corrosion behavior and protective ability of multilayer galvanic coatings of $\mathrm{Zn}$ and $\mathrm{Zn}-\mathrm{Mn}$ alloys in sulfate containing medium", Surf. Coat. Technol., 200, 2006, pp. 5995-6001.

[9] R. Ramanauskas, L. Gudaviciute, R. Juskenas, O. Scit, "Structural and corrosion characterization of pulse plated nanocrystalline zinc coatings", Electrochim. Acta, 53, 2007, pp. 1801-1810.

[10] B. Bozzini, E. Griskonis, A. Fanigliulo, A. Sulcius, "Electrodeposition of Zn-Mn alloys in the presence of thiocarbamide" Surf. Coat. Technol., 154, 2002, pp. 294-303.

[11] R. Ramanauskas, "Structural factor in Zn alloy electrodeposit corrosion", Appl. Surf. Sci., 153, 1999, pp. 53-64. 